\title{
WOMEN'S KNOWLEDGE AND ATTITUDE TOWARD REPRODUCTIVE HEALTH AFTER AN EDUCATIONAL INTERVENTION
}

\author{
Tetti Solehati, Cecep Eli Kosasih, Ermiati \\ Faculty of Nursing, Universitas Padjajaran, Bandung, Indonesia \\ Correspondence: tetti. solehati@unpad.ac.id
}

\begin{abstract}
The risk of health problems especially reproductive health issues is threaten adult women. This may because of inadequate knowledge of reproductive health, and less support related to their attitude. This research aimed to assess the effect of health education on adult women's knowledge and attitude related to health prevention in reproductive health. This study was a quantitative study using quasi-experiment research design with pre and posttest with one group design. 15 adult women involved in this study that were chosen using the accidental sampling technique. The data were gathered in two steps which were before and after an educational intervention. Respondents filled in a valid instrument about health prevention actions in women's reproductive health. The data were analyzed using SPSS software version 22.0, the paired t-test applied in this study. The results showed that the average of respondents' knowledge levels before intervention were 48 , and then increased to 78 after intervention $(\mathrm{p}=0.000)$. The average attitude score was changed from 3.14 to 3.69 after intervention $(p=0.005)$. There is an effect of an educational intervention in improving women's knowledge and attitude. The recommendation, a regular schedule of health education interventions is required by women to prevent or to overcome reproductive health issues.
\end{abstract}

Keywords: Attitude, Education, Knowledge, Women

\section{INTRODUCTION}

Reproductive health is an important aspect for women. All women should have a good understanding and attitude about health promotion and illness prevention in reproductive health to prevent the occurrence of diseases in the reproductive organs. A lack of awareness and knowledge related to the importance of maintaining reproductive health would have negative impacts on women's reproductive health, such as vaginal infections (vulva vaginitis) (Wibowo, 2009). This infection is mostly caused by abnormal organisms including Trichomonas and Candida bacteria (Lowdermilk, 2013). This condition might lead to the occurrence of women's cancer. The vaginal infection would increase vaginal secretion, vulvar irritation, unpleasant odor, discomfort: itching, and urination problems.

Bustan (2007) argued that a lack of hygiene on reproductive organs would a risk factor of cervical cancer cases. Gharoro (2013) said that keeping the cleanliness of reproductive organs is a habit of maintaining reproductive health. Unfortunately, there are many women who are less concerned about the cleanliness of their reproductive organs. In addition, women had low awareness of cancer screening as reproductive 
hormones of women in reproductive ages are active and keep rising.

Improving women's knowledge of reproductive health would an alternative way to deal with lack of women's understanding of reproductive health, and would enhance their awareness in performing health practices in order to prevent women's reproductive issues. Knowledge of reproductive health is an important factor in determining women's health behavior. Lack of information would lead to negative attitudes and misperceptions about physiological processes and risks of unhealthy behavior such as women do not want to behave hygienically (Lamadah, Mohamed, \& El-Khedr, 2015).

Skiner (1938 in Notoatmodjo, 2012) defined that behavior is an individual response to the external stimulus. The formation of an individual behavior starts from the domain of knowledge that would change one's attitude. The health education is an effort to improve women's understanding of reproductive health. Nurses have an important role as educators and reformers to educate women about the importance of maintaining their reproductive health through an educational intervention. Health education is determined as a planned process to improve patients' health awareness, knowledge, and skills (Nursalam \& Effendi, 2009). Curtis, Kanki, et al (2001)'s research in Burkina Faso found that health education related to personal hygiene would change people's behavior to be healthy. Health education can be done individually or in groups. One of the health education methods for groups is the lecture method.

\section{METHODS}

This research was a quantitative study using the quasi-experiment design with pre and posttest in one group design. The population in this study were all women who visited the Cikembulan primary health center in July 2017. The samples were 15 adult women that chosen using the purposive sampling technique. The data were gathered using two instruments: (A) knowledge questionnaire. (B) Attitude questionnaire. The questionnaires were developed by the researchers using some reproductive health Journals articles such as Santina, Wehbe, Ziade, \& Nehme (2013) and Poureslami and Ashtiani (2002), Kozier \& Erb's. (2008), and Nair (2008). Respondents filled in the questionnaire by putting the sign $(\sqrt{ })$ tick on the answer column. This questionnaire used a Likert scale with four choices: SS responses (Strongly Agree), S (Agree), R 
(Doubtful), TS (Disagree), and STS (Strongly Disagree). The statements in the questionnaire consisted of positive and negative statements. The scoring for positive questions were $\mathrm{SS}=5, \mathrm{~S}=4, \mathrm{R}=3, \mathrm{TS}=2$, and $\mathrm{STS}=1$, and for the negative questions were $\mathrm{SS}=1, \mathrm{~S}=2, \mathrm{R}=3, \mathrm{TS}=4$, and $\mathrm{STS}=5$. The higher of the total score the more positive of respondents' attitude. When the score was $\geq 75 \%$ of the total score means the attitude is categorized supportive, and the score $\leq 75 \%$ means it categorized as not supportive attitudes. Data were analyzed using paired t-test for the bivariate analysis.

The data were collected after researchers obtained the site's permission from Kesbangpol office at the Pangandaran Regency. 16 enumerators involved in this study, there were nursing students at Universitas Padjadjaran PSDKU Pangandaran., they attended a training of enumerators before the data collection. The researchers were assisted by nurses in the Cikembulan PHC in identifying potential respondents that match with the inclusion criteria. The criteria of respondents were women in the reproductive ages, able to read, able to hear clearly, and willing to participate in this study. Prospective respondents have been asked for the inform consent related to this study processes. The researchers invited respondents in a room at the Cikembulan Public Health Center. Respondents filled in the questionnaires and followed by an educational intervention about women's health prevention in reproductive health such as cancer screening, menstrual period and vulva hygiene. After completion, they were given the education about reproductive health that includes female reproduction organ and function, menstrual process, ovulation period, pregnancy process, genital care, and early detection of female reproductive cancer. After being educated, the respondents were asked to fill out the questionnaire as an evaluation of the intervention.

\section{RESULTS}

Table 1 Frequency Distribution of Knowledge Levels Before and After Intervention With Respondents at Puskesmas Cikembulan $2017(\mathrm{n}=15)$

\begin{tabular}{lccc}
\hline \multicolumn{1}{c}{ Knowledge Level } & Mean & SD & p-value \\
\hline Before intervention & 48 & 0,57 & 0,000 \\
After intervention & 78 & 0,21 & \\
\hline
\end{tabular}

Table 1 shows that the average of respondents' knowledge level increased from 48 (before intervention) to 78 (after intervention) $(\mathrm{p}=0.000)$. 
Table 2 Frequency Distribution of Attitude Before and After Intervention With Respondents at Puskesmas Cikembulan $2017(\mathrm{n}=15)$

\begin{tabular}{lccc}
\hline Knowledge Level & Mean & SD & $\begin{array}{c}\text { p- } \\
\text { value }\end{array}$ \\
\hline Before intervention & 3,14 & 0,23 & 0,005 \\
After intervention & 3,69 & 0,17 & \\
\hline
\end{tabular}

Table 2 shows that the average of respondents' attitude increased from 3.14 (before intervention) to 3.69 (after intervention) $(p=0.005)$.

\section{DISCUSSION}

The results showed that the average of the knowledge level increased from 48 (before intervention) to 78 (after intervention) $(\mathrm{p}=0.000)$, and the average of respondents' attitude increased from 3.14 (before intervention) to 3.69 (after intervention) $(\mathrm{p}=0.005)$ This study showed that there was a change in the level of knowledge after the intervention. In further analysis, it found that there was a difference in mean of health knowledge on cadres before and after intervention $(\mathrm{p}=0.000)$. The educational intervention that has been done by the researcher had an effect in increasing of respondents' knowledge about the importance of reproductive health understanding for adult women. The importance of an effective education in increasing knowledge in line with Solehati (2014) study. She did a study in Jalupang village and Banggala mulya village Kalijati Subang Regency that involved health cadres in these areas. The study found that education has a significant effect in increasing health cadre's knowledge.

Women need information about women's reproductive health that would be affected by their understanding of reproductive health, sign, and symptoms, and finally may influence their health behavior. The health education was effective in increasing the respondents' knowledge. In addition, the respondents in this study were enthusiasts in participating in the health education provided by the researcher. Furthermore, this activity was also supported by the PHC of Cikembulan both materially and administratively. This study also found that the positive influence of an educational intervention on respondents' attitude $(\mathrm{p}=0,005)$.

The reproductive health education on women in reproductive ages is very important. However, many women had a lack of knowledge about women's reproductive health. This may affect women's health, for example, a risk of reproductive 
tract infections with signs, such as one vaginal discharge and itching in the vagina. In addition, there are myths that believed by women related to women's reproductive health, for examples using betel leaf to maintain the vagina's health especially avoiding whiteness. However, this action would kill normal flora in the vagina areas, as a result, there is a possibility of severe vagina problems.

The health education intervention has an effect in improving women's knowledge and attitude of reproductive health, however, there was not a fixed schedule of this activity. Public Health Center (Puskesmas) would collaborate with local health cadres in promoting women's reproductive health education.

\section{CONCLUSION}

It can be concluded that there is a significant effect of health education on increasing women's knowledge and attitude of reproductive health. The regular program of health education is needed to prevent and overcome reproductive health problems in adult women.

\section{REFERENCE}

Adika, V. O., Ayinde, M. O., \& Jack-Ide I.O. (2013). Self-care practices of menstrual hygiene among adolescents school going girls in Ammasoma Community, Bayelsa State. International Journal of Nursing and Midwifery. 5(5):99-105

Andrews, G. (2009). Buku Ajar Kesehatan Reproduksi Wanita. Jakarta: EGC.

Aryani. (2010). Kesehatan Remaja Problem Dan Solusinya. Jakarta: Salemba Medika. Baradero, Dayrit, dan Siswadi. 2007. Seri Asuhan keperawatan Klien Gangguan Sistem Reproduksi dan Seksualitas. Jakarta: EGC.

Bastable, S. B. (2002). Perawat sebagai pendidik. Jakarta. EGC.

Bieri, F.A., Gray, D.J., Williams, G.M., Raso, G., Li, Y.S., Yuan,L., He, Y., Li, R.S., Guo,F.Y., Li., S.M. \& McManus, D.P. (2013). Health-Education Package to Prevent Worm Infections in Chinese Schoolchildren. N Engl J Med. 368:16031612. DOI: 10.1056/NEJMoa1204885

Biran, A., Schmidt, W.P., Varadharajan, K.S., Rajaraman, D., Kumar, R., Greenland, K., Gopalan, B., Aunger, R. \& Curtis, V. (2014). Effect of a behaviour-change intervention on handwashing with soap in India (SuperAmma): a cluster- 
randomised trial. The Lancet Global Health. 2(3);e145-e154. DOI: http://dx.doi.org/10.1016/S2214-109X(13)70160-8

BPS. 2013. Data Penduduk Kecamatan Tarogong Kidul Kabupaten Garut. Garut: BPS

Burns, SN \& Grove, SK. 2001. Understanding nursing research. 3rd edition.

Philadelphia: Saunders

Curtis, Kanki,B., Cousens,S., Diallo,I., Kpozehouen,A., Sangare,M.'\& Nikiema,M. (2001). Evidence of behaviour change following a hygiene promotion programme in Burkina Faso Valerie. Bulletin of the World Health Organization. 79 (6):518-527

Daryanto \& Muljo, (2012). Model Pembelajaran Inovatif. Yogyakarta: Gara Media.

Dewi, I. G. A. A. N., Sawitri, A. G. S., \& Adiputra, N. (2013). Paparan asap rokok dan higiene diri merupakan faktor risiko lesi prakanker leher rahim di Kota Denpasar tahun. Public Health and Preventive Medicine Archive. 1(1); 84-91

Eswi, A., Helal, H., \& Elarousy, W. (2012). Menstrual Attitude and Knowledge among Egyptian Female Adolescents. Journal of America Science, 555.

Fitriyah, N., Indriani, D., \& Sulistyorini, Y. 2013. Riwayat Kesehatan Reproduksi Remaja Santri. journal.unair.ac.id, (diakses tanggal 10Februari 2016).

Gharoro, L. A. (2013). Menstrual hygiene practices among junior secondary school students in Benin City. Journal of Educational and Social Research, 129.

Hertiningtyas, M., Solehati, T., \& Susanti, I. (2015). Gambaran Faktor Yang Memengaruhi Kebersihan Genitalia Pada Siswi SDN Cikeruh I Dan II Di Jatinangor. Skripsi.

House, S., Mahon, T., \& Cavill, S. (2012). Menstrual hygiene matters; A resource for improving menstrual hygiene around the world. Retrieved from www.wateraid.org/mhm

Joseph, B. (2009). Hygiene Related Adverse Reproductive Health Outcomes Amongst Adolescent Schoolgirls Of Thiruvananthapuram District. Dissertation.

Karout, N. (2015). Knowledge and beliefs regarding menstruation among Saudi nursing students. Journal of Nursing Education and Practice. 6(1):24-30

Kozier, \& Erb's. (2008). Fundamental of Nursing Concepts, Process, and Practices Eight Edition. New Jersey: Pearson Education Inc.

Kumalasari, I., \& Andhyantoro, I. (2012). Kesehatan Reproduksi Untuk Mahasiswa Kebidanan dan Keperawatan. Jakarta: Salemba Medika.

Kusmiran, E. (2011). Kesehatan Reproduksi Remaja Dan Wanita. Jakarta: Salemba Medika.

Lamadah, S. M., Mohamed, H. A.-A., \& El-Khedr, S. M. (2015). Knowledge, attitude and practices of adolescent females regarding reproductive health at makkah al Mukaramah. Life Science Journal, 146.

Leppert \& Peipert, 2004). Primary care for women. Philadelphia, PA; London : Lippincott Williams \& Wilkins

Lowdermik, D. L., Perry, S. E., \& Cashion, K. (2013). Keperawatan Maternitas Edisi 8 Buku 1. Singapore: Elsevier Pte Ltd.

McCaleb A, Cull VV (2000). Socio-cultural influences and self care practices of middle adolescents. J. Pediatr. Nurs. l5(1):30-35.

Mubarak, W. I. (2011). Promosi Kesehatan untuk Kebidanan. Jakarta: Salemba Medika.

Mythili, A. (2007). A study to assess the knowledge and attitude regarding menstrual hygiene among adolscent girls at selected urban and rural schools in Bangalore with a view to develop self instructions model. 
Nair, S. S. (2008). Sharing simple facts: useful information about menstrual health and hygiene. Dalam U. N. Fund, Child's Environment Section (hal. 29-30). New Delhi, India: UNICEF House.

Notoatmodjo, S. (2011). Kesehatan Masyarakat: Ilmu dan Seni. Jakarta: Rineka Cipta. (2012). Promosi Kesehatan dan Ilmu Perilaku. Jakarta : Rineka Cipta.

Nugroho, T. (2010). Kesehatan Wanita, Gender, dan Permasalahannya. Yogyakarta: Nuha Medika.

Nursalam \& Effendi, F. (2009). Pendidikan Dalam Keperawatan. Jakarta: Medika Salemba

Oktaviani, O., Solehati, T. dan Setiawan (2015). Gambaran Perilaku Personal Hygiene Pada Siswa Sekolah Dasar Negeri 1 Andir Kecamatan Baleendah Kabupaten Bandung. Skripsi.

Paath, E. F., Rumdasih, Y., \& Heryati. (2004). Gizi dalam Kesehatan Reproduksi. Jakarta: EGC.

Parvin, M. N., Haque, M. M., Parvin, B., Islam, S. M., Begum, M. S., \& Mondol, S. R. (2015). Hygiene practice during menstruation among adolescent schools girls. The American Journal of Innovative Research and Applied Science, 99.

Patricia, A. (2005). Buku Ajar Fundamental Keperawatan Consep, Edisi 4. Jakarta: EGC.

Polit, Beck, \& Hungler, 2001). Essentials of Nursing Research: Methods, Appraisal and Utilization. Lippincott Williams and Wilkins.

Poltekkes Depkes Jakarta I. (2010). Kesehatan Remaja: Problem dan Solusinya. Jakarta: Salemba Medika.

Portney \& Watkins (2000). Foundations of clinical research: Applications to practice. Mcgraw-Hill/appleton \& Lange

Perry, A. G., \& Potter, P. A. (2006). Clinical nursing skills \& techniques. St. Louis: Mosby.

Poureslami, M., \& Ashtiani, F. O. (2002). Assessing Knowledge, Attitudes, and Behavior of Adolescent Girls in Suburban Districts of Tehran About Dysmenorrhea and Menstrual Hygiene. Journal of International Women's Studies, 3(2), 51-61.

Rahman, N. (2014). Faktor-faktor yang berhubungan dengan perilaku personal hygiene pada saat menstruasi di SMP Muhammadiyah 5 Yogyakarta.

Rajakumari G, A. (2015). A S tudy on Knowledge regarding Menstrual Hygiene among Adolescent School Girls. Global Journal of Current Research, 111-116.

Santina, T., Wehbe, N., Ziade, F. M., \& Nehme, M. (2013). Assessment of Beliefs and Practices Relating to Menstrual Hygienen of Adolescent Girls in Lebanon. International Journal of Health Sciences and Research, 75-88.

Sari, I.P., Firani, K.F. \& Yuliatun, L. (2013). Pengaruh Pendidikan Kesehatan tentang Menstruasi terhadap Perubahan Perilaku Menstrual Hygiene Remaja Putri untuk Pencegahan Infeksi Saluran Reproduksi (ISR). BIMIKI. 2(1):11-18. 